\title{
The intake, digestion and protein degradation of grazed herbage by early-weaned lambs
}

\author{
BY G. J.CRUICKSHANK*, D. P. POPPI† AND A. R. SYKES \\ Animal and Veterinary Sciences Group, Lincoln University, Canterbury, New Zealand
}

(Received 21 September 1990 - Accepted 19 September 1991)

\begin{abstract}
Sixty-four intact lambs and twenty-four lambs fitted with a duodenal cannula were weaned at 6 weeks of age and grazed pure species swards of either lucerne (Medicago sativa), white clover (( Trifolium repens), ryegrass (Lolium perenne) or prairie grass (Bromus catharticus) for 6 weeks. Intake and duodenal digesta flow were estimated when lambs were 8 and 12 weeks of age. Lambs grazing the two legume species grew at a similar rate, as did lambs grazing the two grass species. Legumes promoted a $38 \%$ higher growth rate than grasses. The higher growth rate of lambs grazing legumes was associated with a $36 \%$ higher digestible organic matter intake (DOMI; 29.5 and $21.7 \mathrm{~g} / \mathrm{kg}$ body-weight per $\mathrm{d}$ for legume and grass respectively) and a $33 \%$ higher duodenal non-ammonia-nitrogen (NAN) flow (1.22 and $0.92 \mathrm{~g} / \mathrm{kg}$ body-weight per $\mathrm{d}$ respectively). There was no species difference in the site of organic matter digestion; on average 0.56 of DOMI was apparently digested in the rumen and 0.77 of DOMI was truly digested in the rumen. There was no difference in duodenal NAN flow, relative to DOMI (average, $43 \mathrm{~g} / \mathrm{kg}$ ) or to organic matter apparently digested in the rumen $(80 \mathrm{~g} / \mathrm{kg})$. Similarly, there was no difference in microbial $N$ flow relative to duodenal NAN $(0.50 \mathrm{~g} / \mathrm{g})$ and organic matter apparently $(41 \mathrm{~g} / \mathrm{kg})$ or truly $(29 \mathrm{~g} / \mathrm{kg})$ digested in the rumen. It was concluded that the higher growth rates achieved by lambs grazing legumes were due to higher intakes which increased the total quantity of nutrients supplied despite more protein being lost in the rumen of lambs consuming legumes.
\end{abstract}

Early weaning: Grazing intake: Nutrient supply: Lambs

Early weaning of lambs has the potential to increase the efficiency of pasture utilization by making the highly digestible nutrients available to the lamb directly rather than via the ewe (Jagusch et al. 1970; Rattray et al. 1976). However, early weaning on pasture has not been widely adopted in practice despite experimental evidence that early-weaned lambs can grow at similar rates to suckled lambs (Jagusch et al. 1970, 1971).

The high growth potential and, therefore, high nutrient requirement of young lambs make them sensitive to diet quality and nutrient supply. The growth rate of grazing lambs is dependent on herbage intake, the nutrients absorbed and the efficiency of utilization of absorbed nutrients. However, the majority of studies on the digestion of fresh herbage have used housed animals (MacRae \& Ulyatt, 1974; Ulyatt \& MacRae, 1974; Ulyatt \& Egan, 1979; Beever et al. 1985) due to the problems associated with grazing studies. Recently, grazing studies involving sheep (Corbett et al. 1982; Corbett \& Pickering, 1983) and cattle (Beever et al. 1986a,b; Ulyatt et al. 1988) have been conducted, but young, rapidly-growing lambs do not appear to have been examined.

The present experiment studied the intake, nutrient supply and growth rate of earlyweaned lambs grazing four pasture species offered at high dry matter (DM) allowances. A preliminary report has appeared (Cruickshank et al. 1985).

\footnotetext{
* Present address: AgResearch, PO Box 85, Hastings, New Zealand.

$\dagger$ Present address: Dept Agriculture, University of Queensland 4072, Australia. For reprints.
} 


\section{METHODS}

Animals

Ninety-four South Suffolk $\times$ Coopworth ram lambs were used. They were selected in two groups based on their date of birth and weaned as two different groups at a mean age of 6 weeks. The birth dates of the two groups were approximately $14 \mathrm{~d}$ apart. Twenty-four lambs were fitted with a ' $\mathrm{T}$ '-shaped cannula in the duodenum (CAN lambs) and six lambs with an oesophageal fistula (OF lambs), 4-7 d before weaning. Lambs were removed from their dam for $4-6 \mathrm{~h}$ before surgery under standard general anaesthetic and aseptic procedures, following which they were promptly returned and continued to suckle vigorously. This removed the potential trauma associated with simultaneous surgery and weaning, and also permitted, subsequently, simultaneous weaning of CAN and intact (INT) lambs.

Sixteen INT lambs and six CAN lambs grazed each of the four pastures. The six OF lambs were rotated around the pastures as required. Lambs were approximately $15 \mathrm{~kg}$ body-weight (W) at the start of the experiment.

\section{Pasture}

Pure species swards of lucerne (Medicago sativa var. Rere), white clover (Trifolium repens var. Huia), ryegrass (Lolium perenne var. Ruanui) and prairie grass (Bromus catharticus var. Matua) were strip grazed in $2 \mathrm{~d}$ shifts for the 6 weeks of the experiments. Herbage mass was estimated by cutting a series of quadrats to ground level. When lambs were 8 and 12 weeks old the herbage mass ( $\mathrm{kg} \mathrm{DM} / \mathrm{ha}$ ) was respectively: lucerne 2790,3230 , white clover 2460, 2020, ryegrass 1900,1740 , prairie grass 1660, 1965. Actual DM allowances (kg $\mathrm{DM} /$ lamb per d) were, at 8 and 12 weeks of age respectively: lucerne $5 \cdot 4,5 \cdot 1$, white clover $4 \cdot 1,4 \cdot 7$, ryegrass $6 \cdot 8,6 \cdot 1$, prairie grass $6 \cdot 2,6 \cdot 0$.

\section{Timing}

The experiment was carried out between 29 September and 25 November (spring). The difficulties involved in simultaneously sampling lambs on all four pasture species were overcome by selecting animals into two groups based on their date of birth. Weaning dates were such that the study of lambs grazing lucerne and prairie grass commenced $14 \mathrm{~d}$ before the study with white clover and ryegrass, but lambs of both groups were about 6 weeks of age at the start of the experiment. This was facilitated by colour-coding lambs at birth so they could be easily and accurately aged without handling. This also aided removal of ewes and lambs when surgery was to be performed. The surgery, weaning and sampling dates are given in Table 1 .

\section{Digesta flow}

Duodenal flow of nitrogen, non-ammonia N (NAN), organic matter (OM) and microbial $\mathrm{N}$ was estimated in CAN lambs at 8 and 12 weeks of age by the double-marker technique of Faichney (1975, 1980). Portable infusion pumps ('Siropump'; Everest Electronics, South Australia) were used to infuse continuously $10 \mu \mathrm{Ci}{ }^{103} \mathrm{Ru}$ phenanthroline $\left({ }^{103} \mathrm{Ru}-\mathrm{P}\right)$ and $50 \mu \mathrm{Ci}{ }^{51} \mathrm{Cr}$ EDTA in $150 \mathrm{ml}$ water into the rumen daily for $8 \mathrm{~d}$, via a temporary catheter. $\mathrm{Na}_{2}{ }^{35} \mathrm{SO}_{4}(150 \mu \mathrm{Ci})$ was added daily to the infusate during the last $3 \mathrm{~d}$. Samples of duodenal digesta were obtained twice daily over the last $4 \mathrm{~d}$ of infusion. Sampling times were staggered to represent $3 \mathrm{~h}$ intervals over a theoretical $24 \mathrm{~h}$ day. Approximately $100 \mathrm{~g}$ digesta were obtained at each sampling, from which $30 \mathrm{~g}$ whole digesta and $30 \mathrm{~g}$ filtrate (strained through nylon cloth) were retained. Digesta were bulked for the first and last $2 \mathrm{~d}$ periods and frozen at $-20^{\circ}$ until analysis. Microbial $\mathrm{N}$ was estimated as a proportion of 
Table 1. Dates of surgery, weaning and measurements, at 8 and 12 weeks of age, for lambs grazing prairie grass (Bromus catharticus) or lucerne (Medicago sativa), and ryegrass (Lolium perenne) or white clover (Trifolium repens)

\begin{tabular}{|c|c|c|}
\hline & $\begin{array}{l}\text { Prairie grass } \\
\text { and lucerne }\end{array}$ & $\begin{array}{l}\text { Ryegrass and } \\
\text { white clover }\end{array}$ \\
\hline Surgery & 21 and 23 September & 6 and 7 October \\
\hline Weaning & 29 September & 13 October \\
\hline \multicolumn{3}{|l|}{ Measurements } \\
\hline \multicolumn{3}{|l|}{ Lambs 8 weeks old } \\
\hline Digesta flow & $11-15$ October & $25-29$ October \\
\hline Intake & $11-15$ October & 25-29 October \\
\hline Marker retention time & 15-17 October & $28-30$ October \\
\hline Rumen fill & 14 October & 29 October \\
\hline \multicolumn{3}{|l|}{ Lambs 12 weeks old } \\
\hline Digesta flow & $8-12$ November & 22-26 November \\
\hline Intake & 8-11 November & 2I-24 November \\
\hline Marker retention time & 11-13 November & 24-26 November \\
\hline Rumen fill & 10 November & 25 November \\
\hline
\end{tabular}

NAN in reconstituted 'true' digesta (last $2 \mathrm{~d}$ only) by reference to the ratio of ${ }^{35} \mathrm{~S}: \mathrm{N}$ in isolated bacteria and duodenal digesta, corrected for $\mathrm{NH}_{3}$ content (Mathers \& Miller, 1980).

\section{Intake}

Intake was estimated when lambs were 8 and 12 weeks old. Faecal output was estimated by reference to chromic oxide dilution in INT lambs and ${ }^{103} \mathrm{Ru}-\mathrm{P}$ dilution in CAN lambs. $\mathrm{Cr}_{2} \mathrm{O}_{3}$ was dosed twice daily ( $1 \mathrm{~g} \mathrm{Cr}$ in a gelatin capsule) at approximately 08.00 and 16.00 hours and faecal sampling from the rectum occurred at the same times. Three INT lambs from each group were fitted with faecal collection bags to provide a representative sample for concentration of $\mathrm{Cr}_{2} \mathrm{O}_{3}$ to which twice-daily grab-sample concentration was corrected (Langlands et al. 1963). Dosing occurred over a $10 \mathrm{~d}$ period with faeces being sampled over the last $5 \mathrm{~d}$. CAN lambs were fitted with faecal collection bags so that bulked representative samples were easily obtained In vivo digestibility was estimated by reference to indigestible acid-detergent fibre (Penning \& Johnson, 1983) and also by cellulase (EC 3.2.1.4) in vitro organic matter digestibility of oesophageal boli (McLeod \& Minson, 1978).

\section{Rumen $\mathrm{NH}_{3}$ concentration}

At 8 and 12 weeks of age, eight INT lambs from each pasture species were slaughtered to obtain data on the weight of digesta in various parts of the digestive tract for another experiment. Lambs were slaughtered at discrete intervals corresponding to the beginning and end of the morning and afternoon grazing periods, with two lambs being slaughtered on each occasion. Samples of mixed rumen fluid were removed for analysis of $\mathrm{NH}_{3}$ concentration.

\section{Fractional outflow rate $(F O R)$ of markers from the rumen}

The FOR from the rumen of the digesta markers ${ }^{103} \mathrm{Ru}-\mathrm{P}$ and ${ }^{51} \mathrm{Cr}$ EDTA was estimated in CAN lambs on two occasions, following the cessation of continuous infusion, from the rate of decline of marker concentration in duodenal digesta and faeces. A single pulse of marker infusate (equivalent to $40 \%$ of the daily infusion rate) was introduced into the 
rumen of four INT lambs on each pasture species and the FOR from the rumen was estimated from the rate of decline of marker concentration in faeces.

\section{Live-weight gain $(L W G)$}

Lambs were weighed once weekly and before slaughter. LWG was estimated from the regression live-weight $v$. time.

\section{Analytical techniques}

Radioactivity of ${ }^{51} \mathrm{Cr}$ and ${ }^{103} \mathrm{Ru}-\mathrm{P}$ was measured simultaneously in a dual-channel autogamma scintillation spectrometer (Packard, USA).

Total $\mathrm{N}$ content of all samples was determined in $0.5 \mathrm{~g}$ DM using a Kjeldahl digestion system (Tecator, Hoganas, Sweden) with a potassium sulphate-copper sulphate $(19: 1$, $\mathrm{w} / \mathrm{w}$ ) catalyst and an automated filtration unit (Multi-Dosimat E415, Metrohm, Herison, Switzerland). $\mathrm{NH}_{3}-\mathrm{N}$ concentration in rumen fluid and digesta was determined using sodium tetraborate to increase the $\mathrm{pH}$, distilling into boric acid and titrating with hydrochloric acid.

Ash-free neutral-detergent fibre (NDF) was analysed as described by Van Soest \& Wine (1967). Indigestible acid-detergent fibre (IADF) on extrusa and faeces was analysed as described by Penning \& Johnson (1983), using a $7 \mathrm{~d}$ incubation with cellulase ('Onozuka' FA, Yakult, Japan).

\section{Statistical analysis}

Statistical analysis of effects of age of animal (i.e. measurement period) within pasture species and effects of pasture species was by analysis of variance and Student's $t$ test. Further comparisons were made using regression analysis of duodenal NAN flow of $N$ intake, digestible organic matter intake (DOMI) and apparent organic matter digestion in the rumen. Values are expressed as means with their standard errors.

\section{RESULTS}

\section{$L W G$}

LWG of INT lambs was $230,227,308$ and $321 \mathrm{~g} / \mathrm{d}$ for prairie grass, ryegrass, lucerne and white clover respectively (Table 2 ). LWG of prairie grass and ryegrass animals were significantly less than those of the lucerne and white clover animals $(P<0 \cdot 05)$. LWG was significantly lower for CAN lambs $(33 \% ; P<0.05)$ on all pasture species. However, LWG $/ \mathrm{kg}$ DOMI was similar for the two groups of lambs within each pasture species.

\section{Intake and digestibility}

There appeared to be significant diurnal variation in faecal $\mathrm{Cr}_{2} \mathrm{O}_{3}$ concentration in INT lambs, as reflected by the differences between spot and bulked samples. Bulked samples had higher $\mathrm{Cr}$ concentration than spot samples for all pasture species $(13,17,27$ and $44 \%$ higher for prairie grass, ryegrass, white clover and lucerne respectively) which reflects the difference between an average concentration based on complete collection of faeces and one based on two sampling points only. The spot-sample concentration was adjusted for each animal by the appropriate proportion determined for each pasture type.

Intake $(\mathrm{g} / \mathrm{kg} \mathrm{W})$ was similar at 8 and 12 weeks of age for each pasture type and, therefore, results were grouped within pasture species. The OM intake and OM digestibility (from indigestible ADF) by CAN and INT lambs are given in Table 2. There was no difference in OM digestibility between CAN and INT lambs. However, OM intake $(\mathrm{g} / \mathrm{kg}$ W) was consistently lower for CAN lambs, $(16,18,26$ and $27 \%$ for prairie grass, ryegrass, lucerne and white clover respectively; $P<0.05$ ). For both CAN and INT lambs the OM 
Table 2. Live-weight gain ( $L W G ; g / d)$, organic matter intake $(O M I ; g / k g$ live-weight $), O M$ digestibility $(O M D)$ and $L W G$ per $\mathrm{kg}$ digestible OMI $(D O M I ; \mathrm{g} / \mathrm{kg})$ of cannulated $(C A N)$ and intact (INT) lambs grazing prairie grass (Bromus catharticus), ryegrass (Lolium perenne), white clover (Trifolium repens) and lucerne (Medicago sativa)*

(Mean values with their standard errors for lambs at 8 and 12 weeks of age)

\begin{tabular}{|c|c|c|c|c|c|c|c|c|}
\hline & \multicolumn{2}{|c|}{ LWG } & \multicolumn{2}{|c|}{ OMI } & \multicolumn{2}{|c|}{ OMD } & \multicolumn{2}{|c|}{ LWG/DOMI } \\
\hline & Mean & $\mathrm{SE}$ & Mean & $\mathrm{SE}$ & Mean & SE & Mean & $\mathrm{SE}$ \\
\hline \multicolumn{9}{|c|}{ Prairie grass } \\
\hline CAN & 156 & $18 \cdot 4$ & $25 \cdot 1$ & 1.61 & $0 \cdot 81$ & $0 \cdot 012$ & 396 & $47 \cdot 3$ \\
\hline INT & 230 & $8 \cdot 1$ & $30 \cdot 0$ & 1.44 & $0 \cdot 80$ & 0.014 & 425 & $16 \cdot 3$ \\
\hline \multicolumn{9}{|l|}{ Ryegrass } \\
\hline CAN & 153 & $20 \cdot 0$ & $28 \cdot 8$ & 1.82 & $0 \cdot 81$ & 0.006 & 335 & $26-9$ \\
\hline INT & 227 & $8 \cdot 8$ & $35 \cdot 3$ & 1.82 & 0.80 & 0.006 & 351 & $13 \cdot 5$ \\
\hline \multicolumn{9}{|c|}{ White clover } \\
\hline CAN & 202 & $21 \cdot 4$ & $33 \cdot 4$ & $1 \cdot 11$ & $0-84$ & $0-004$ & 316 & $20 \cdot 2$ \\
\hline INT & 321 & $18 \cdot 3$ & $46 \cdot 0$ & 2.99 & 0.83 & $0 \cdot 005$ & 341 & $30 \cdot 7$ \\
\hline \multicolumn{9}{|l|}{ Lucerne } \\
\hline $\mathrm{CAN}$ & 211 & $10 \cdot 5$ & $36 \cdot 5$ & $1 \cdot 74$ & 0.85 & $0 \cdot 007$ & 320 & $12 \cdot 6$ \\
\hline INT & 308 & $24 \cdot 8$ & $49 \cdot 2$ & 1.86 & $0 \cdot 84$ & $0 \cdot 005$ & 297 & $13-3$ \\
\hline
\end{tabular}

* For details of procedures, see pp. $350-352$.

intake was higher on legumes ( 29 and $46 \%$ for CAN and INT respectively; $P<0.05$ ), and no difference was observed between prairie grass and ryegrass, or between lucerne and white clover.

\section{Composition of oesophageal extrusa}

The composition of oesophageal extrusa is given in Table 3 together with the OM and NDF digestibility determined by indigestible ADF in extrusa and faeces. The composition and digestibility of lucerne and white clover was similar during measurement periods at 8 and 12 weeks of age (average NDF, $191 \mathrm{~g} / \mathrm{kg} \mathrm{DM}$; average OM digestibility, 0.84), apart from lucerne NDF digestibility (0.80 and 0.72 during measurement periods at 8 and 12 weeks of age respectively). In contrast, grasses tended to increase in NDF content with time and decrease in $\mathrm{N}$ content between measurement periods (Table 3). Digestibility of OM and NDF was similar during measurement periods for ryegrass, but was higher at the early measurement period of prairie grass (Table 3 ).

\section{Sites of nutrient digestion}

The proportion of DOMI apparently digested in the rumen was similar for all pasture species $(0 \cdot 52-0 \cdot 58 ; P>0 \cdot 1$; Table 4$)$. A higher proportion of digestible NDF was digested in the rumen of lambs grazing grasses than for lambs grazing legumes (mean 0.88 for grasses and 0.76 for legumes; Table 5).

$\mathrm{N}$ intake was significantly different for all pasture species (prairie grass $<$ ryegrass $<$ white clover $<$ lucerne; $P<0.05$; Table 6 ), caused by differences in intake and herbage $\mathrm{N}$ content. However, duodenal NAN flow was similar for prairie grass and ryegrass, and for lucerne and white clover, due to variable $\mathrm{N}$ losses across the rumen. Duodenal NAN flow was higher in lambs grazing legumes (mean $1.22 \mathrm{~g} \mathrm{NAN} / \mathrm{kg} \mathrm{W}$ per d) than in lambs grazing grasses (mean $0.92 \mathrm{~g} \mathrm{NAN} / \mathrm{kg} \mathrm{W}$ per d). Relative to DOMI, duodenal NAN flow was not significantly higher for legumes than for grasses (average, 45 and $41 \mathrm{~g}$ NAN/kg DOMI 
Table 3. The organic matter $(O M)$, neutral-detergent fibre $(N D F)$ and nitrogen content of oesophageal extrusa $(\mathrm{g} / \mathrm{kg} \mathrm{DM})$ and the digestibility of organic matter $(O M D)$ and NDF (NDFD) as determined by the indigestible acid-detergent fibre method by lambs aged 8 and 12 weeks of age grazing prairie grass (Bromus catharticus), ryegrass (Lolium perenne), white clover (Trifolium repens) and lucerne (Medicago sativa)*

(Mean values with their standard errors for cannulated and intact lambs)

\begin{tabular}{|c|c|c|c|c|c|c|c|c|c|c|}
\hline & \multicolumn{2}{|c|}{ OM } & \multicolumn{2}{|c|}{ NDF } & \multicolumn{2}{|c|}{$\mathbf{N}$} & \multicolumn{2}{|c|}{ OMD } & \multicolumn{2}{|c|}{ NDFD } \\
\hline & Mean & $\mathrm{SE}$ & Mean & $\mathrm{SE}$ & Mean & $\mathrm{SE}$ & Mean & $\mathrm{SE}$ & Mean & $\mathrm{SE}$ \\
\hline \multicolumn{11}{|l|}{ Prairie grass } \\
\hline 8 weeks old & 858 & $7 \cdot 5$ & 361 & $25 \cdot 5$ & 33 & $2 \cdot 3$ & 0.84 & 0.003 & 0.86 & 0.005 \\
\hline 12 weeks old & 848 & $7 \cdot 3$ & 496 & $31 \cdot 0$ & 28 & 1.6 & $0 \cdot 80$ & 0.010 & 0.80 & 0.006 \\
\hline \multicolumn{11}{|l|}{ Ryegrass } \\
\hline 8 weeks old & 842 & $9 \cdot 6$ & 312 & $31 \cdot 9$ & 45 & 1.0 & $0 \cdot 80$ & 0.007 & $0 \cdot 81$ & $0 \cdot 008$ \\
\hline 12 weeks old & 866 & $2 \cdot 1$ & 375 & $19 \cdot 4$ & 36 & $1 \cdot 1$ & $0-80$ & 0.006 & 0.81 & 0.006 \\
\hline \multicolumn{11}{|l|}{ White clover } \\
\hline 8 weeks old & 871 & 3.9 & 187 & $5 \cdot 0$ & 49 & 0.7 & 0.84 & 0.003 & 0.73 & 0.011 \\
\hline 12 weeks old & 865 & $2 \cdot 4$ & 200 & $4 \cdot 1$ & 44 & 0.5 & 0.82 & 0.005 & 0.72 & 0.011 \\
\hline \multicolumn{11}{|l|}{ Lucerne } \\
\hline 8 weeks old & 854 & $7 \cdot 3$ & 198 & $4 \cdot 6$ & 49 & $2 \cdot 2$ & $0-86$ & 0.003 & 0.80 & 0.003 \\
\hline 12 weeks old & 864 & $2 \cdot 8$ & 180 & $5 \cdot 9$ & 52 & $2 \cdot 1$ & 0.83 & $0 \cdot 005$ & 0.72 & 0.006 \\
\hline
\end{tabular}

* For details of procedures, see pp. 350-352.

respectively). Relative to the quantity of OM apparently digested in the rumen, there was no difference between pasture species (average, $80 \mathrm{~g}$ NAN/ $\mathrm{kg}$ OM apparently digested in the rumen).

There was no difference between plant species in the flow of microbial $\mathrm{N}$ relative to duodenal NAN, OM apparently or truly digested in the rumen or DOMI (Table 6). However, the degradability of protein was significantly greater in the legumes than in the grasses (Table 6).

\section{Rumen $\mathrm{NH}_{3}$ concentration}

The concentration of $\mathrm{NH}_{3}$ is shown in Table 7. There was, in general, an increase in concentration throughout the day, which resulted in the concentration in the afternoon being, on average, $60 \%$ higher than in the morning. Legumes tended to promote higher concentrations than grasses, although ryegrass during the 8 -weeks-of-age measurement period displayed a similar average concentration to that of white clover.

\section{Marker outflow rate}

The FOR of digesta markers, estimated from duodenal digesta and faeces, is shown in Table 8. The concentration of ${ }^{51} \mathrm{Cr}$ EDTA in duodenal digesta declined rapidly with the result that insufficient samples were obtained from several lambs, particularly on white clover. Estimated from duodenal digesta, lambs grazing legumes tended to display higher FOR of ${ }^{103} \mathrm{Ru}-\mathrm{P}$ than lambs grazing grasses $(0 \cdot 120,0 \cdot 109,0 \cdot 068$ and $0 \cdot 092 / \mathrm{h}$ for lucerne, white clover, ryegrass and prairie grass respectively), although the difference between prairie grass and white clover was not significant $(P>0 \cdot 05)$. There was no significant difference between plant species in the FOR of ${ }^{51} \mathrm{Cr}$ EDTA, although lucerne displayed a much higher value $(0.177)$ than prairie grass and ryegrass $(0 \cdot 142$ and $0 \cdot 123$ respectively). Estimated from faeces, the trends remained similar, although the level of significance altered. There was no 


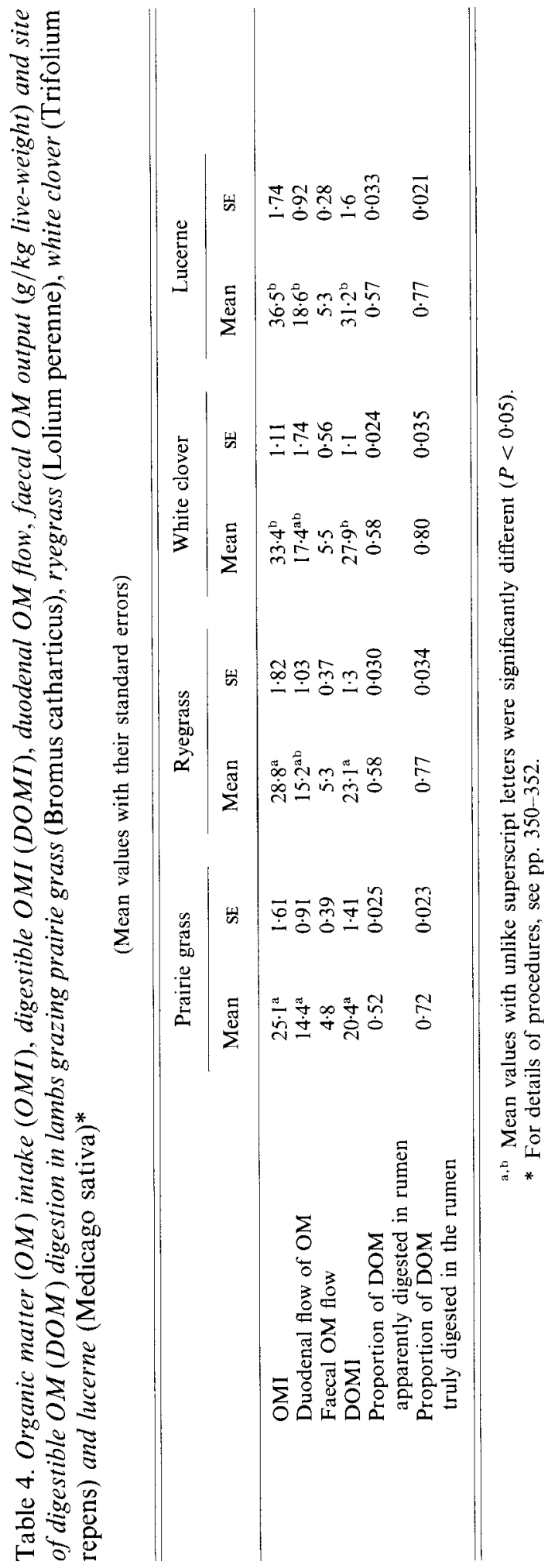




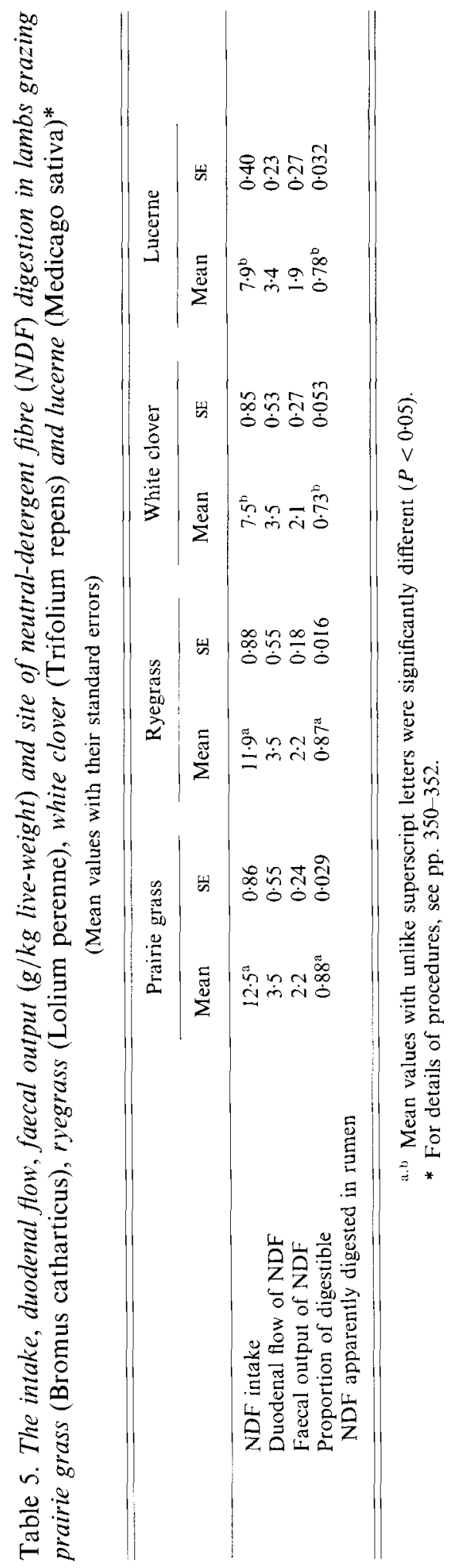


DIGESTION OF FRESH HERBAGE

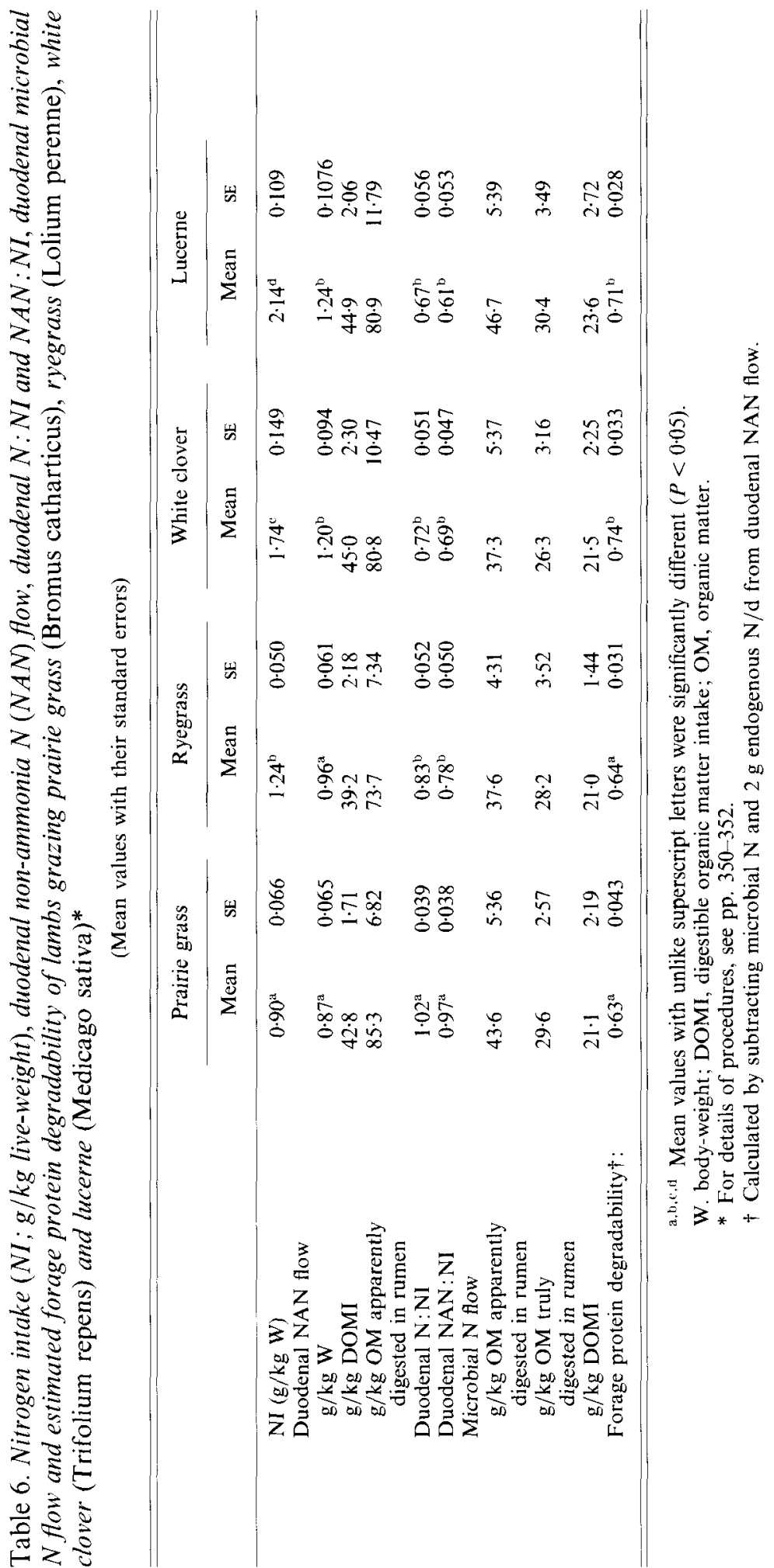


Table 7. The concentration of ammonia in rumen fluid $(\mathrm{mg} / \mathrm{l})$ of lambs aged 8 and 12 weeks of age at the start (PRE) and end (POST) of the morning $(A M)$ and afternoon (PM) grazing periods in lambs grazing prairie grass (Bromus catharticus), ryegrass (Lolium perenne), white clover (Trifolium repens) and lucerne (Medicago sativa)*

(Mean values with their standard errors)

\begin{tabular}{|c|c|c|c|c|c|c|c|c|c|c|}
\hline & \multicolumn{2}{|c|}{ PRE-AM } & \multicolumn{2}{|c|}{ POST-AM } & \multicolumn{2}{|c|}{ PRE-PM } & \multicolumn{2}{|c|}{ POST-PM } & \multicolumn{2}{|c|}{ Average } \\
\hline & Mean & $\mathrm{SE}$ & Mean & $S E$ & Mean & $\mathrm{SE}$ & Mean & $\mathrm{SE}$ & Mean & $\mathrm{SE}$ \\
\hline \multicolumn{11}{|l|}{8 weeks old } \\
\hline Prairie grass & 156 & $11 \cdot 5$ & 162 & 46.0 & 183 & $47 \cdot 0$ & 274 & $4 \cdot 5$ & 194 & $22 \cdot 0$ \\
\hline Ryegrass & 180 & $44 \cdot 5$ & 486 & $30 \cdot 1$ & 702 & 113.5 & 640 & 980 & 502 & 99.6 \\
\hline White clover & 354 & $133 \cdot 5$ & 474 & 0.5 & 546 & 36.5 & 536 & $41 \cdot 0$ & 478 & $39 \cdot 7$ \\
\hline Lucerne & 822 & 100 & 687 & 87.0 & 828 & $110 \cdot 0$ & 816 & $42 \cdot 0$ & 788 & $35 \cdot 3$ \\
\hline \multicolumn{11}{|l|}{12 weeks old } \\
\hline Prairie grass & 47 & $26 \cdot 5$ & 67 & $28 \cdot 5$ & 401 & $23 \cdot 5$ & 400 & $58 \cdot 0$ & 229 & $66 \cdot 5$ \\
\hline Ryegrass & 210 & 110.0 & 236 & $48 \cdot 0$ & 400 & 36.5 & 492 & 27.5 & 335 & $50 \cdot 4$ \\
\hline White clover & 295 & $36 \cdot 5$ & 289 & 87.5 & 546 & $57 \cdot 0$ & 744 & $141 \cdot 5$ & 469 & $79 \cdot 4$ \\
\hline Lucerne & 546 & $119 \cdot 0$ & 621 & 73.5 & 688 & $65 \cdot 0$ & 846 & 103.0 & 675 & $54 \cdot 5$ \\
\hline
\end{tabular}

* For details of procedures, see pp. $350-352$.

Table 8. The fractional outflow rate of the digesta markers ${ }^{103} R u$ phenanthroline $\left({ }^{103} R u-P\right)$ and ${ }^{51} \mathrm{Cr}$-EDT A from the rumen of cannulated (CAN) and intact (INT) lambs grazing prairie grass (Bromus catharticus), ryegrass (Lolium perenne), white clover (Trifolium repens) and lucerne (Medicago sativa) estimated from the rate of decline of marker concentration in duodenal digesta and faeces*

(Mean values with their standard errors for the average no. of samples analysed per animat on each plant species; four INT lambs and six CAN lambs were involved on two occasions)

\begin{tabular}{|c|c|c|c|c|c|c|}
\hline & \multicolumn{3}{|c|}{${ }^{103} \mathrm{Ru}-\mathrm{P}$} & \multicolumn{3}{|c|}{${ }^{51} \mathrm{Cr}-\mathrm{EDTA}$} \\
\hline & Mean & $\mathrm{SE}$ & $n$ & Mean & SE & $n$ \\
\hline \multicolumn{7}{|l|}{ Prairie grass } \\
\hline CAN Duodenal & 0.092 & 0.0059 & 12 & $0 \cdot 142$ & 0.0100 & 10 \\
\hline CAN Faeces & 0.081 & 0.0038 & 12 & $0 \cdot 106$ & 0.0067 & 12 \\
\hline INT Faeces & $0 \cdot 076$ & 0.0035 & 8 & $0 \cdot 108$ & 0.0100 & 8 \\
\hline \multicolumn{7}{|l|}{ Ryegrass } \\
\hline CAN Duodenal & 0.068 & 0.0047 & 10 & $0 \cdot 123$ & 0.0262 & 7 \\
\hline CAN Faeces & $0 \cdot 066$ & 0.0033 & 10 & $0 \cdot 098$ & 0.0039 & 10 \\
\hline INT Faeces & $0 \cdot 078$ & 0.0043 & 8 & $0 \cdot 105$ & 0.0049 & 8 \\
\hline \multicolumn{7}{|l|}{ White clover } \\
\hline CAN Duodenal & $0 \cdot 109$ & 0.0077 & 9 & \multicolumn{3}{|c|}{ Insufficient samples } \\
\hline CAN Faeces & 0.096 & 0.0045 & 10 & $0 \cdot 132$ & 0.0086 & 10 \\
\hline INT Faeces & $0 \cdot 105$ & 0.0057 & 8 & $0 \cdot 130$ & 0.0216 & 8 \\
\hline \multicolumn{7}{|l|}{ Lucerne } \\
\hline CAN Duodenal & $0 \cdot 120$ & 0.0058 & 10 & 0.177 & 0.0194 & 5 \\
\hline CAN Faeces & 0.092 & 0.0057 & 10 & 0.129 & 0.0122 & 10 \\
\hline INT Faeces & $0 \cdot 106$ & 0.0056 & 8 & $0 \cdot 135$ & 0.0096 & 8 \\
\hline
\end{tabular}

* For details of procedures, see pp. $350-352$. 
difference between CAN and INT lambs in the FOR of ${ }^{103} \mathrm{Ru}-\mathrm{P}$ and ${ }^{51} \mathrm{Cr}$ EDTA estimated from marker concentration in the faeces. FOR of markers from the rumen estimated from marker concentration in duodenal digesta was higher than that estimated from marker concentration in the faeces, especially for ${ }^{51} \mathrm{Cr}$ EDTA.

\section{DISCUSSION}

\section{$L W G$}

The LWG of intact lambs was high, and was similar to the high growth rates observed by McLean et al. (1965) and Jagusch et al. (1971) for early-weaned lambs grazing pure species swards of white clover, lucerne and perennial ryegrass. Growth rates were similar for lambs grazing the two legumes (approximately $315 \mathrm{~g} / \mathrm{d}$ ) and for lambs grazing the two grasses (approximately $230 \mathrm{~g} / \mathrm{d}$ ). The similarity between prairie grass and ryegrass was surprising considering the higher NDF and lower $\mathrm{N}$ content of prairie grass. However, the digestibility of prairie grass was higher than that of ryegrass at 8 weeks of age. The decline in quality of prairie grass over the experiment was unfortunate and was probably related to its growing season, which is considerably earlier than the other pasture species. Had prairie grass been studied earlier in its growing season the performance of lambs may have been better.

In a study such as this it is difficult to avoid confounding effects such as time and pasture species. This was apparent with prairie grass which was difficult to keep in a vegetative state through grazing management. However, the objective of the study was to examine nutrient supply in spring herbage for a particular age of lamb. Thus, the results have application for the period studied but do not address seasonal differences.

The lower intake and growth rate of CAN lambs cannot be readily explained. The lambs quickly became accustomed to the regular handling and often ruminated whilst being sampled. Sampling that occurred during a grazing period rarely took longer than $0.5 \mathrm{~h}$ for the group as digesta flowed quickly from the cannula in these times. Because of the staggered timetable major grazing periods were not sampled on the same day and a reduction in grazing time was unlikely to be the cause of the lower growth rate.

The greater growth rate of lambs grazing legumes was associated with greater intake and duodenal NAN flow. The NAN flow:DOMI ratio was $10 \%$ higher in lambs grazing legumes but it was unlikely that this increase could have caused the $38 \%$ increase in growth rate. The higher DOMI $(36 \% ; \mathrm{g} / \mathrm{kg} \mathrm{W})$ and duodenal NAN flow $(33 \% ; \mathrm{g} / \mathrm{kg} \mathrm{W})$ were the major differences.

\section{Site of nutrient digestion}

$O M$. The proportion of DOMI apparently digested in the rumen was similar on all pasture species $(0.52-0.58)$. These values tended to fall in the lower limit of reported data for animals consuming fresh herbage. However, the DOMI $(\mathrm{g} / \mathrm{kg} \mathrm{W})$ observed in the present experiment was high and the low values for the proportion of digestible OM apparently digested in the rumen may have been caused by the high intakes. There have been conflicting reports of the effect of plant species on the site of OM digestion. Ulyatt \& MacRae (1974) observed the proportion of rumen digestion of digestible OM to be 0.55 for short-rotation ryegrass and 0.64 and 0.65 for perennial ryegrass and white clover respectively. Similarly, Beever et al. (1985) observed higher values for the proportion of rumen digestion of digestible $\mathrm{OM}$ in cattle offered perennial ryegrass indoors $(0 \cdot 68-0 \cdot 74)$ than in cattle offered white clover indoors $(0.51-0.56)$, whilst Ulyatt et al. (1988) found values of 0.73 and 0.70 for ryegrass and clover respectively. However, Thomson \& Beever (1980), analysing a range of data, could find no evidence for species differences and estimated a mean value of $0 \cdot 6$. Beever et al. (1986 b) observed similar values of 0.69 and 0.71 
in cattle grazing perennial ryegrass and white clover respectively. Correcting for duodenal OM of microbial origin they calculated that 0.97 of the OM apparently digested in the digestive tract was truly digested in the rumen. This emphasized the extensive degradation of dietary OM which occurred in the rumen. In the present experiment the proportion of DOMI truly digested in the rumen (assuming microbial $\mathrm{N}$ is $10 \%$ of microbial $\mathrm{OM}$; Beever et al. 1986a) ranged from $0 \cdot 72-0 \cdot 80$ (Table 4). These lower values probably reflect the shorter retention time of digesta in the rumen of these young lambs (Cruickshank et al. 1990).

$N D F$. The higher concentration of NDF in grasses led to lambs consuming $58 \%$ more NDF $(\mathrm{g} / \mathrm{kg} \mathrm{W})$ from grasses than from legumes $(P<0 \cdot 05)$. However, duodenal flow and faecal output of NDF were similar for all pasture species because of the higher digestibility of NDF in grasses ( 0.82 and 0.74 , for grasses and legumes respectively) and the higher proportion of digestible NDF digested in the rumen of lambs grazing grasses compared with lambs grazing legumes $(0.88$ and 0.76 respectively).

The partitioning of NDF digestion between the rumen and hind-gut has been poorly studied in sheep consuming fresh herbage. However, most digestion occurs in the rumen for both cellulose and hemicellulose in fresh and conserved forage (Ulyatt \& MacRae, 1974). In general, the proportion of digestible NDF digested in the rumen lies in the range 0.85-0.95 (Hogan, 1973; Weston \& Margan, 1979; Kennedy, 1985; Alam et al. 1987). The values observed in the present experiment appear low, particularly for legumes, and this is probably due to high FOR of digesta from the rumen, as reflected by the high outflow rate of markers from the rumen (Table 8). Lower values of 0.59-0.73 (average, 0.67 ) have been observed in lambs consuming a ground and pelleted roughage-concentrate diet which also had a high FOR (Margan et al. 1982).

$N$. The $\mathrm{N}$ concentration was, on average, $37 \%$ higher in legumes than in grasses. Combined with the higher $\mathrm{OM}$ intake, lambs grazing legumes had a considerably higher daily $\mathrm{N}$ intake than lambs grazing grasses ( 1.9 and $1.1 \mathrm{~g} \mathrm{~N} / \mathrm{kg} \mathrm{W}$ respectively). However, $\mathrm{N}$ transactions in the rumen considerably altered the quantity of $\mathrm{N}$ flowing past the duodenum, with no change for lambs grazing prairie grass but losses of 17,28 and $33 \%$ for lambs grazing ryegrass, white clover and lucerne respectively (Table 6). Duodenal NAN flow was lower than $\mathrm{N}$ intake for all plant species $(0.97,0.78,0.69$ and $0.61 \mathrm{~g} \mathrm{NAN} / \mathrm{g} \mathrm{N}$ intake for prairie grass, ryegrass, white clover and lucerne respectively). Increased $\mathrm{N}$ loss was associated with increased rumen $\mathrm{NH}_{3}$ concentration (mean 211, 418,629 and $576 \mathrm{mg}$ $\mathrm{NH}_{3}-\mathrm{N} / 1$ for prairie grass, ryegrass, white clover and lucerne respectively).

$\mathrm{NH}_{3}-\mathrm{N}$ represented 5-7\% of total $\mathrm{N}$ flow past the duodenum and was similar for all plant species. NAN flow was similar for both grass species and for both legume species (Table 6). However, the increased flow observed in lambs grazing legumes was associated with increased DOMI $(36 \%)$ and a $41 \%$ increase in OM apparently digested in the rumen (g OM apparently digested in the rumen $/ \mathrm{kg} \mathrm{W}$ ) with the result that duodenal NAN flow was only $10 \%$ (per $\mathrm{kg}$ DOMI) and $2 \%$ (per $\mathrm{kg}$ OM apparently digested in the rumen) higher in lambs grazing legumes.

Initial comparison of these results with information in the literature is confounded by the generally higher intakes observed in the present experiment and the high $\mathrm{N}$ content of the diets. However, it is important to recognize that digestion is a dynamic process and comparison of individual values may be misleading. Therefore, the results obtained in the present experiment have been compared with published information in the form of general relationships, using relevant values from published studies on the digestion of fresh herbage conducted with sheep (indoor studies, MacRae \& Ulyatt, 1974; Ulyatt \& MacRae, 1974; Ulyatt \& Egan, 1979; grazing studies, Ulyatt, 1971; Corbett et al. 1976, 1982) and cattle (indoors, Beever et al. 1985, 1986a; grazing, Beever et al. 1986 b; Ulyatt et al. 1988). 
Table 9. The flow of non-ammonia nitrogen $(N A N)$ into the small intestine, in relation to digestible organic matter $(O M)$ intake $(D O M I)$ and the quantity of $O M$ apparently digested in the rumen, in animals consuming fresh grass or legume herbage

\begin{tabular}{|c|c|c|c|}
\hline Reference & & $\mathrm{g} \mathrm{NAN} / \mathrm{kg}$ DOMI & $\begin{array}{c}\text { g NAN/kg OM apparently } \\
\text { digested in rumen }\end{array}$ \\
\hline \multirow[t]{2}{*}{ MacRae \& Ulyatt (1974) } & Grass & $42 \cdot 5$ & $72 \cdot 8$ \\
\hline & Legume & $39 \cdot 2$ & $59 \cdot 8$ \\
\hline \multirow{2}{*}{ Corbett et al. (1976) } & Grass & $53 \cdot 5$ & $89 \cdot 0$ \\
\hline & Legume & $47 \cdot 2$ & $71 \cdot 5$ \\
\hline \multirow[t]{2}{*}{ Ulyatt \& Egan (1979) } & Grass & $43 \cdot 9$ & $77 \cdot 6$ \\
\hline & Legume & $46 \cdot 4$ & $83 \cdot 7$ \\
\hline \multirow[t]{2}{*}{ Corbett et al. (1982) } & Grass & $47 \cdot 1$ & $76 \cdot 1$ \\
\hline & Legume & 45.9 & $77 \cdot 6$ \\
\hline \multirow{2}{*}{ Beever et al. (1985) } & Grass & $36 \cdot 2$ & $52 \cdot 6$ \\
\hline & Legume & $37 \cdot 0$ & $52 \cdot 4$ \\
\hline \multirow[t]{2}{*}{ Beever et al. (1986a) } & Grass & $31 \cdot 6$ & $44 \cdot 8$ \\
\hline & Legume & 45.0 & $85 \cdot 5$ \\
\hline \multirow[t]{2}{*}{ Present results } & Grass & 410 & $79 \cdot 6$ \\
\hline & Legume & $45 \cdot 0$ & $80 \cdot 8$ \\
\hline
\end{tabular}

Increasing rumen $\mathrm{NH}_{3}$ concentration was associated with increasing $\mathrm{N}$ losses across the rumen, as reflected by the duodenal $\mathrm{N}: \mathrm{N}$ intake and $\mathrm{NAN}$ flow: $\mathrm{N}$ intake ratios (Table 6). $\mathrm{N}$ losses across the rumen have been related to $\mathrm{N}$ intake (MacRae \& Ulyatt, 1974; Ulyatt \& Egan, 1979) or to $\mathrm{N}$ concentration in the diet (Beever et al. 1986 b). The relationship between duodenal NAN flow, as a proportion of $\mathrm{N}$ intake, and $\mathrm{N}$ content of the diet ( $\mathrm{g} \mathrm{N} / \mathrm{kg} \mathrm{OM}$ ), derived from the present experiment was duodenal NAN:N intake = $1.392-0.0132 \mathrm{~N}(\mathrm{~g} \mathrm{~N} / \mathrm{kg} \mathrm{OM})\left(n 8, r^{2} 0.74\right)$. This was similar to the equation derived from cattle by Beever et al. (1986b) and Ulyatt et al. (1988) of $y=1.430-0.0169 x$, where $y$ and $x$ are the variables in the previously given equation.

Equality between $\mathrm{N}$ intake and duodenal NAN flow was predicted to occur when dietary $\mathrm{N}$ concentration was 25.5 and $29.8 \mathrm{~g} \mathrm{~N} / \mathrm{kg}$ OM from Ulyatt $e t$ al. (1988) and the present experiment respectively. These relationships reflect the ability of rumen microbes to capture dietary $\mathrm{N}$ and suggest that $\mathrm{N}$ transactions in the rumen are similar in early-weaned lambs and cattle. This also explains why the large differences in $\mathrm{N}$ intake observed in the present experiment were largely removed by transactions in the rumen and further emphasizes the importance of the rumen in modifying the nutrients available for absorption.

In the present experiment, duodenal NAN flow was closely related to DOMI (mean, $43 \mathrm{~g} \mathrm{NAN} / \mathrm{kg}$ DOMI) and to the quantity of OM apparently digested in the rumen (mean, $80 \mathrm{~g} \mathrm{NAN} / \mathrm{kg}$ OM apparently digested in the rumen). These results are comparable with a range of values in the literature, relating to animals consuming fresh herbage (Table 9), although low values were observed by Beever et al. $(1985,1986 a)$. Apart from the study of Beever et al. (1986a) there was no difference in NAN flow $(\mathrm{g} / \mathrm{kg}$ DOMI) between grasses and legumes.

Individual treatment values from the literature and the results from the present experiment, relating NAN flow to the small intestine, N intake, DOMI and OM apparently digested in the rumen $(\mathrm{g} / \mathrm{kg} \mathrm{W})$ were analysed by regression analysis to determine which factor(s) were most closely related to NAN flow to the small intestine. The resulting regression equations are shown in Table 10. The correlation between NAN flow to the small intestine and OM apparently digested in the rumen was very low $\left(r^{2} 0.350\right)$ and was 
Table 10. Regressions relating non-ammonia nitrogen $(N A N)$ flow to the small intestine $\left(N A N_{s i}, g / k g\right.$ live-weight $)$ to $N$ intake $(N I, g / k g$ live-weight $), D O M I(\mathrm{~g} / \mathrm{kg}$ live-weight $)$ and $O M$ apparently digested in the rumen, $\mathrm{g} / \mathrm{kg}$ live-weight) for animals consuming fresh herbage including those used in the present study ( $\mathrm{n} 85$ )

\begin{tabular}{|c|c|}
\hline Regressions & $r^{2}$ \\
\hline $\mathrm{NAN}_{\mathrm{si}}=0 \cdot 480^{* * *}(\mathrm{SE} 0 \cdot 0032) \mathrm{NI}+0 \cdot 275^{* * *}(\mathrm{SE} 0 \cdot 0030)$ & 0.764 \\
\hline $\mathrm{NAN}_{\mathrm{si}}=0.0348^{* * *}(\mathrm{SE} 0 \cdot 0003) \mathrm{DOMI}+0 \cdot 105^{*}(\mathrm{SE} 0.0050)$ & 0.679 \\
\hline $\mathrm{NAN}_{\mathrm{si}}=0.0343^{* * *}$ (SE 0.00056) OM apparently digested in rumen $+0.318^{* * *}$ (SE 0.0064) & $0-350$ \\
\hline $\mathrm{NAN}_{\mathrm{si}}=0.346^{* * *}(\operatorname{SE} 0.0058) \mathrm{NI}+0.0121^{* *}(\operatorname{SE} 0.00045) \mathrm{DOMI}+0 \cdot 188^{* *}(\mathrm{SE} 0.0043)$ & 0.786 \\
\hline $\begin{array}{l}\mathrm{NAN}_{\mathrm{si}}=0.501^{* * *}(\mathrm{SE} 0.0045) \mathrm{NI}-0.00316^{\mathrm{NS}}(\mathrm{SE} 0.000476) \mathrm{OM} \text { apparently digested in } \\
\text { rumen }+0.291^{* * *}(\mathrm{SE} 0.0039)\end{array}$ & 0.766 \\
\hline
\end{tabular}

$$
\begin{aligned}
& \text { NS, not significant. } \\
& { }^{* * *} P<0 \cdot 001,{ }^{* *} P<0.01,{ }^{*} P<0 \cdot 05
\end{aligned}
$$

markedly higher for DOMI ( $\left.r^{2} 0.679\right)$, a cruder estimate of energy available for microbial synthesis. $\mathrm{N}$ intake provided the highest correlation with NAN flow to the small intestine $\left(r^{2} 0.764\right)$ and this was only marginally improved by including DOMI $\left(r^{2} 0.786\right)$ or OM apparently digested in the rumen $\left(r^{2} 0766\right)$ in the regression. Ulyatt \& Egan (1979) observed that duodenal $\mathrm{N}$ flow was best predicted by $\mathrm{N}$ intake, although large variation was observed between individual experiments. Similarly, Beever et al. (1986a) observed highly significant relationships between $\mathrm{N}$ intake and duodenal NAN flow within treatments, but the relationships altered markedly between treatments. Therefore, derived relationships between $\mathrm{N}$ intake and NAN flow to the small intestine may yield erroneous predictions if applied to individual sets of experimental data. These findings also highlight the large variation which exists between NAN flow to the small intestine and OM apparently digested in the rumen which might be expected given that microbial $\mathrm{N}$ is a variable part of duodenal NAN and that OM apparently digested in the rumen is a poor indicator of energy available in the rumen (Beever et al. 1986a,b).

Microbial $\mathrm{N}$ yields relative to $\mathrm{OM}$ apparently digested in the rumen $(\mathrm{g} / \mathrm{kg}$; Table 6$)$ were similar to values collated by Beever \& Siddons (1986) for cattle and sheep consuming fresh forage. When these microbial $N$ yields were related to $O M$ truly digested in the rumen $(\mathrm{g} / \mathrm{kg}$; Table 6) no difference was found between the forages, with values ranging from 28 to $31 \mathrm{~g}$ microbial $\mathrm{N} / \mathrm{kg}$ OM truly digested in the rumen. These are within the range collated by Beever \& Siddons (1986), and agree closely with the sheep data but are less than the cattle data. It is not known why cattle values should be higher than those of sheep. Expression on the basis of OM truly digested in the rumen is more meaningful as an available energy term and the consistent narrow range in microbial synthesis across these four forage types provides a basis for future prediction. Overall protein degradability was high for these fresh herbages and higher for the legumes $(0 \cdot 72)$ compared with the grasses $(0 \cdot 64$; Table 6$)$. This was reflected in rumen $\mathrm{NH}_{3}$ concentration. On average, approximately 0.5 of the duodenal NAN flow was microbial in origin with no differences between the forages, and this was markedly less than the average value of 0.72 collated by Beever $\&$ Siddons (1986).

\section{Conclusions}

Lambs grazing legumes grew significantly faster than lambs grazing grasses, although there was a marked similarity between the two legume species and between the two grass species. The higher growth rates observed in lambs grazing legumes were associated with higher 
levels of intake and increased flow of NAN to the small intestine, but it was not possible to differentiate between the relative importance of energy and protein. Digestion in the rumen significantly altered the quantity of $\mathrm{N}$ flowing to the small intestine, particularly for legumes, where significant losses of dietary $\mathrm{N}$ across the rumen were observed. Related to DOMI, the duodenal flow of NAN was slightly higher in lambs grazing legumes, but the major difference appeared to be in the total quantity of nutrients supplied.

The authors acknowledge the surgery performed by Dr A. Familton and the technical assistance of N. Jay, P. Wilson, G. Elmsley, J. Lassen, Carolyn Smith and Kay Mackie.

\section{REFERENCES}

Alam, M. R., Lawson, G. D., Poppi, D. P. \& Sykes, A. R. (1987). Comparison of the site and extent of digestion of nutrients of a forage in kids and lambs. Journal of Agricultural Science, Cambridge 109, 583-589.

Beever, D. E., Dhanoa, M. S., Losada, H. R., Evans, R. T., Cammell, S. B. \& France, J. (1986a). The effect of forage species and stage of harvest on the processes of digestion occurring in the rumen of cattle. British Journal of Nutrition 56, 439-454.

Beever, D. E., Losada, H. R., Cammell, S. B., Evans, R. T. \& Haines, M. J. (1986 b). Effect of forage species and season on nutrient digestion and supply in grazing cattle. British Journal of Nutrition 56, 209-225.

Beever, D. E. \& Siddons, R. C. (1986). Digestion and metabolism in the grazing ruminant. In Control of Digestion and Metabolism in Ruminants, pp. 479-497 [L. P. Milligan, W. L. Grovum and A. Dobson, editors]. Englewood Cliffs: Prentice Hall.

Beever, D. E., Thomson, D. J., Ulyatt, M. J., Cammell, S. B. \& Spooner, M. C. (1985). The digestion of fresh perennial ryegrass (Lolium perenne $\mathrm{L}$. cv. Melle) and white clover (Trifolium repens $\mathbf{L}$. cv. Blanca) by growing cattle fed indoors. British Journal of Nutrition 54, 763-775.

Corbett, J. L., Furnival, E. P., Inskip, M. W. \& Pickering, F. S. (1982). Protein digestion in grazing sheep. Forage Protein in Ruminant Animal Production. British Society of Animal Production Occasional Publication no. 6, pp. 141 143. Thames Ditton: British Society of Animal Production.

Corbett, J. L., Lynch, J. J., Nicol, G. R. \& Beeston, J. W. U. (1976). A versatile peristaltic pump designed for grazing lambs. Laboratory Practice 25, 458-462.

Corbett, J. L. \& Pickering, F. S. (1983) Estimation of daily flows of digesta in grazing sheep. Australian Journal of Agricultural Research 34, 193-210.

Cruickshank, G. J., Poppi, d. P. \& Sykes, A. R. (1985). Intake and duodenal protein flow in early weaned lambs grazing white clover, lucerne, ryegrass and prairie grass. Proceedings of the New Zealand Society of Animal Production 45, 113-116.

Cruickshank, G. J., Poppi, D. P., Sykes, A. R. \& Familton, A. S. (1990). Effect of age, abomasal cannulation and rumen catheterization on intake and site of digestion by early weaned lambs. Journal of Agricultural Science, Cambridge 114, 49-54.

Faichney, G. J. (1975). The use of markers to partition digestion within the gastro-intestinal tract of ruminants. In Digestion and Metabolism in the Ruminant, pp. 277-291 [I. W. McDonald and A. C. I. Warner, editors]. Armidale: University of New England Publishing Unit.

Faichney, G. J. (1980) The use of markers to measure digesta flow from the stomach of sheep fed once daily. Journal of Agricultural Science, Cambridge 94, 313-318.

Hogan, J. P. (1973). Intestinal digestion of subterranean clover by sheep. Australian Journal of Agricultural Research 24, 587-598.

Jagusch, K. T., Clark, V. R. \& Jay, N. P. (1970). Lamb production from animals weaned at 3 to 5 weeks of age on to lucerne. New Zealand Journal of Agricultural Research 13, 808 - 814.

Jagusch, K. T., Mitchell, R. M., McConnell, G. R., Fennessy, P. F., Woodlock, M. R. \& Jay, N. P. (1971). Nutrition of the growing lamb: studies at Lincoln College. Proceedings of the New Zealand Society of Animal Production 31, 121128.

Kennedy, P. M. (1985). Influences of cold exposure on digestion of organic matter, rates of passage of digesta in the gastrointestinal tract, and feeding and rumination behaviour in sheep given four forage diets in the chopped, or ground and pelleted form. British Journal of Nutrition 53, 159173

Langlands, J. P., Corbett, J. L., McDonald, I. \& Reid, G. W. (1963). Estimation of the faeces output of grazing animals from the concentration of chromium sesquioxide in a sample of faeces. 1. Comparison of estimates from samples taken at fixed times of day with faeces outputs measured directly. British Journal of Nutrition 17 , 211218.

McLean, J. W., Thomson, G. G., Jagusch, K. T. \& Lawson, B. M. (1965). Lamb growth and development in relation to pasture species. Proceedings of the Ruakura Farmers Conference Week pp. 34 40. Ruakura: MAF.

McLeod, M. N. \& Minson, D. J. (1978). The accuracy of the pepsin cellulase technique for estimating dry matter digestibility in vivo of grasses and legumes. Animal Feed Science and Technology 3, 277-287. 
MacRae, J. C. \& Ulyatt, M. J. (1974). Quantitative digestion of fresh herbage by sheep II. The site of digestion of some nitrogenous constituents. Journal of Agricultural Science, Cambridge 82, 309-319.

Margan, D. E., Faichnev, G. J., Graham, N. McC. \& Donnelly, J. B. (1982). Digestion of a ground and pelleted diet in the stomach and intestines of young sheep from two breeds. Austratian Journal of Agricultural Research 33, 617-627.

Mathers, J. C. \& Miller, E. L. (1980). A simple procedure using ${ }^{35} \mathrm{~S}$ incorporation for the measurement of microbial and undegraded food protein in ruminant digesta. British Journal of Nutrition 43, 503-514.

Penning, P. D. \& Johnson, R. H. (1983). The use of internal markers to estimate herbage digestibility and intake 2. N Indigestible acid detergent fibre. Journal of Agricultural Science, Cambridge 100, 133-138.

Rattray, P. V., Morrison, M. C. L. \& Farquhar, P. A. (1976). Performance of early-weaned lambs on lucerne and pasture. Proceedings of the New Zealand Society of Animal Production 36, 179-183.

Thomson, D. J. \& Beever, D. E. (1980). The effect of conservation and processing on the digestion of forages by ruminants. In Digestive Physiology and Metabolism in Ruminants, pp. 291--308 [Y. Ruckebusch and P. Thivend, editors). Lancaster: MTP Press Ltd.

Ulyatt, M. J. (1971). Studies on the causes of the differences in pasture quality between perennial ryegrass, shortrotation ryegrass and white clover. New Zealand Journal of Agricultural Research 14, 352-367.

Ulyatt, M. J. \& Egan, A. R. (1979). Quantitative digestion of fresh herbage by sheep. V. The digestion of four herbages and prediction of sites of digestion. Journal of Agricultural Science, Cambridge 92, 605-616.

Ulyatt, M. J. \& MacRae, J. C. (1974). Quantitative digestion of fresh herbage by sheep. 1. The site of digestion of organic matter, energy, readily fermentable carbohydrate, structural carbohydrate and lipid. Journal of Agricultural Science, Cambridge 82, 295-307.

Ulyatt, M. J., Thomson, D. J., Beever, D. E., Evans, R. T. \& Haines, M. J. (1988). The digestion of perennia1 ryegrass (Lolium perenne cv. Melle) and white clover (Trifolium repens cv. Blanca) by grazing cattle. British Journal of Nutrition 60, 137-149.

Van Soest, P. J. \& Wine, R. H. (1967). Use of detergents in the analysis of fibrous feeds. IV. Determination of plant cell wall constituents. Journal of the Association of Official Analytical Chemists 50, 50-55.

Weston, R. H. \& Margan, D. E. (1979). Herbage digestion in the stomach and intestine of weaner lambs at different stages of their maturing. Australian Journal of Agricultural Research 30, 543-549. 